\title{
THEORETICAL DISAGREEMENT AND THE SEMANTIC STING
}

\section{Dale Smith*}

Scott Shapiro recently suggested that:

... positivism is particularly vulnerable to Dworkin's critique in Law's Empire. To overlook this challenge, which most positivists have done, is to ignore the most serious threat facing legal positivism at the beginning of the twenty-first century. ${ }^{1}$

I shall argue that Shapiro is right to regard Dworkin's critique in Chapter 1 of Law's Empire. $^{2}$ as posing a serious threat to legal positivism. In fact, the threat is even greater than he realizes, and may apply not only to positivism but to other theories of law as well. To show this, however, I first need to show that most commentators misunderstand Dworkin's critique in Chapter 1.

While Chapter 1 has spawned an extensive secondary literature (most of it highly critical), there is surprisingly little agreement about the goal of that chapter. Commentators often interpret Chapter 1 as seeking to refute positivism. ${ }^{3}$ However,

\footnotetext{
* Faculty of Law, Monash University. I am grateful to Christopher Birch, Patrick Emerton, Jeff Goldsworthy and Kevin Walton - and especially to an anonymous referee for $O J L S$ - for their very helpful comments.

1 SJ Shapiro, 'The "Hart-Dworkin" Debate: A Short Guide for the Perplexed' in A Ripstein (ed), Ronald Dworkin (CUP, New York 2007) 50.

${ }^{2}$ R Dworkin, Law's Empire (Hart Publishing, Oxford 1998). Henceforth, this work is referred to as 'LE' followed by the relevant page number, and references to 'Chapter 1' are to Chapter 1 of Law'S Empire.

${ }^{3}$ In addition to Shapiro (n 1), see, eg, KE Himma, ‘Ambiguously Stung: Dworkin's Semantic Sting Reconfigured' (2002) 8 Legal Theory 145-183.
} 
some regard Dworkin as instead attacking a particular approach to conceptual explanation, ${ }^{4}$ while others interpret him as having multiple objectives. ${ }^{5}$

Nevertheless, there is general agreement that Chapter 1 contains a single key argument, often referred to as the 'semantic sting argument' and which I will abbreviate as 'the SSA'. It is also generally accepted that the SSA critiques a view I will call 'criterialism'. Criterialism is the claim that - for any word (or concept) - we share a rule setting out criteria for using that word (or applying that concept), and that these shared criteria constitute the meaning of the word (or the content of the concept). ${ }^{6}$ There is controversy over whether criterialism is the ultimate target of the SSA, or whether Dworkin attacks criterialism in order to achieve some further goal (such as refuting positivism). There is, however, general agreement that the SSA involves critiquing criterialism, and that it is the key argument contained in Chapter 1.

Shapiro challenges this consensus. He contends that the key argument in Chapter 1 is not the SSA, but rather what I shall call 'the argument from theoretical disagreement' (or 'the ATD' for short). According to Shapiro, the ATD is an objection to positivism. It contends that positivists are committed to there being agreement among legal officials about what Dworkin calls 'the grounds of law'.

\footnotetext{
${ }^{4}$ See, eg, J Raz, 'Two Views of the Nature of the Theory of Law: A Partial Comparison' in J Coleman (ed), Hart's Postscript: Essays on the Postscript to the Concept of Law (OUP, Oxford 2001).

${ }^{5}$ For example, Jules Coleman interprets Chapter 1 as both a critique of positivism and a defence of 'normative jurisprudence': J Coleman, The Practice of Principle: In Defence of a Pragmatist Approach to Legal Theory (OUP, Oxford 2001) 155-6 \& 179-83.

${ }^{6}$ Two qualifications are called for. First, one might claim that criterialism is true of some words (or concepts), but not others: see, eg, Raz (n 4) 24. I shall be concerned only with the word 'law' (or the concept of law). Second, criterialism can be viewed as either a claim about concepts or a claim about words. Because some commentators discuss the concept of law while others discuss the word 'law', and because I believe that this difference is unimportant for our purposes, I shall refer interchangeably to criteria for applying the concept of law and criteria for using the word 'law'.
} 
However, the objection continues, legal officials often disagree about the grounds of law, something that positivists cannot explain.

Shapiro acknowledges that Chapter 1 also contains the SSA. However, he regards the SSA as clearly flawed, whereas we have seen that he regards the ATD as posing a serious challenge to positivism. The primary aim of his essay is to identify that challenge and to sketch the strategy he believes positivists should use to meet it.

The first three parts of the present article set out my own understanding of Chapter 1. I argue that Shapiro is right to distinguish two parts to Chapter 1, but that he underestimates the scope of the ATD and may also misunderstand the role of the SSA. In Part 1, I argue that the ATD is best understood as an objection to any theory of law that denies that there can be disagreement about the grounds of law, and that 'the grounds of law' should be understood more broadly than is generally realized. In Part 2, I argue that the SSA is not meant as an objection to positivism or a defence of 'normative jurisprudence'. Rather, it seeks to explain why most contemporary theories of law make the mistake identified in the ATD - that is, it seeks to explain why they deny that there can be disagreement about the grounds of law. It is in the course of doing this that the SSA purports to show that (a variant of) criterialism is untenable. I then consider, in Part 3, an important objection to my interpretation of Chapter 1.

The final two parts of the article assess the threat posed by Chapter 1 to contemporary theories of law, especially positivism. In Part 4, I consider an influential objection to the SSA. I argue that this objection is unsuccessful, but that it 
suggests an alternative objection that does refute the SSA. However, neither objection undermines the ATD, and - on my interpretation, like Shapiro's - the ATD is the key argument in Chapter 1. In Part 5, I argue that, if disagreement about the grounds of law is as prevalent as the ATD contends, we must reject what I shall call 'orthodox' positivism. Orthodox positivism claims that, in any legal system, there is general agreement among the officials of that system about what the criteria of legal validity are. I then suggest that there are two main ways in which positivists might respond to the ATD. One involves defending orthodox positivism, on the basis that what appears to be disagreement about the grounds of law is in fact something else. The other involves abandoning orthodox positivism in favour of a version of positivism that allows for such disagreement. I argue that pursuing either strategy will be more difficult than Dworkin's critics realize.

\section{The ATD}

A. What is the ATD?

The ATD contends that most contemporary legal philosophers have an implausibly narrow account of the types of disagreement that can arise in legal practice. ${ }^{7}$ This is most clearly true of positivists, but may be true of other legal philosophers as well. However, to see why the ATD should be understood in this way, we need to examine Chapter 1 in some detail.

\footnotetext{
${ }^{7}$ My understanding of the ATD is heavily influenced by Shapiro (n 1) 35-9. However, two important differences between my understanding and Shapiro's are discussed in Section 1C.
} 
This article was first published in the

(2010) 30(4) Oxford Journal of Legal Studies 635-661

Dworkin argues that - to understand legal practice - we must recognize that it is argumentative:

Every actor in the practice understands that what it permits or requires depends on the truth of certain propositions that are given sense only by and within the practice; the practice consists in large part in deploying and arguing about these propositions. People who have law make and debate claims about what law permits or forbids that would be impossible - because senseless - without law and a good part of what their law reveals about them cannot be discovered except by noting how they ground and defend those claims. (LE 13)

It follows that an important part of understanding legal practice is understanding the disagreements that arise in the course of that practice. To that end, Dworkin suggests, we need to draw two distinctions. The first is between what he calls 'propositions of law' and the 'grounds' of law. Propositions of law are statements about the content of the law - that is, they are statements about what the law requires, permits or prohibits. The grounds of law, by contrast, are what determine the truth or falsity of propositions of law (and hence determine the content of the law).

This leads into Dworkin's second distinction. There are, he says, two ways in which legal practitioners might disagree about the truth of propositions of law. Firstly, they might agree about what the grounds of law are but disagree about whether those grounds are satisfied in a particular case:

Lawyers and judges might agree, for example, that the speed limit is 55 in California if the official California statute book contains a law to that effect, but disagree about 
whether that is the speed limit because they disagree about whether, in fact, the book does contain such a law. (LE 4-5)

Dworkin labels this 'empirical' disagreement. He contrasts it with 'theoretical' disagreement, which is disagreement '.. about the grounds of law, about which other kinds of propositions, when true, make a particular proposition of law true.' (LE 5) For example, two judges might agree on what the pertinent statutes and precedents say about a particular point of law, but disagree about what the law is because they disagree about whether statutes and precedents are the only relevant grounds of law.

The ATD is an objection to any theory of law that denies that theoretical disagreement can exist among competent legal practitioners. ${ }^{8}$ According to Dworkin, this includes the theories of law held by most contemporary legal philosophers. The most influential such theory, or group of theories, is legal positivism. Dworkin claims that positivists adopt what he calls the 'plain fact' view, which he suggests represents the dominant account of the grounds of law in modern jurisprudence (LE 33, 37). According to the plain fact view, the law '... is only a matter of what legal institutions, like legislatures and city councils and courts, have decided in the past.' (LE 7) In other words, the grounds of law consist solely of plain (i.e. empirical) facts about what certain legal actors have said or done. It follows that the content of the law does not depend in any way on moral considerations. ${ }^{9}$

\footnotetext{
${ }^{8}$ This statement needs qualifying in two ways. Firstly, I argue in Part 5 that the ATD targets not only theories that deny that theoretical disagreement exists, but also theories that allow that theoretical disagreement exists but deny that it can be widespread. Secondly, to make the ATD more clearly applicable to positivism, I will focus on whether theoretical disagreement exists among legal officials. (For the sake of brevity, when referring to theoretical disagreement, I will often omit the qualifier 'among legal officials'.)

${ }^{9}$ This clearly overlooks inclusive legal positivism (which Dworkin does not regard as a genuine form of positivism: R Dworkin, Taking Rights Seriously (Harvard UP, Cambridge Mass. 1977) ch 3). However, I argue in Part 5 that the ATD poses a threat to both exclusive and inclusive legal positivism.
} 
Dworkin contends that the plain fact view - and hence positivism - is committed to claiming that the only type of disagreement legal officials can have about the content of the law is empirical disagreement about what legislatures, courts, etc have decided in the past. This is because, according to the plain fact view, the content of the law depends solely upon such plain facts. This leaves no room for theoretical disagreement. ${ }^{10}$

Dworkin claims that positivism may not be the only theory of law that denies that theoretical disagreement exists. He suggests that positivism's traditional rivals natural law theory and legal realism - may also claim that there is general agreement about the grounds of law (though they differ from positivism in their claims about what the agreed grounds of law are). ${ }^{11}$ For example, natural law theory could be seen as claiming '.. that lawyers follow criteria that are not entirely factual, but at least to some extent moral, for deciding which propositions of law are true.' (LE 35)

The problem confronting such theories is that it seems that theoretical disagreement does exist. Dworkin discusses four cases where judges and lawyers appear to disagree about what the grounds of law are, and infers from these examples (which he refers to as the 'sample cases') that theoretical disagreements appear to be commonplace. For example, in Tennessee Valley Authority v Hill, ${ }^{12}$ the court had to

\footnotetext{
${ }^{10}$ A layperson might not realize that the content of the law depends solely on plain facts, and so could engage in theoretical disagreement. However, on the plain fact view, any competent legal official knows that the law's content depends solely on plain facts (and knows which plain facts are relevant): LE 7.

${ }^{11}$ If legal officials agree about what the grounds of law are, how could positivists and natural lawyers disagree on this point? The answer is that it may not be obvious what legal officials are agreeing to, since the agreement may not be express but rather implicit in their practices.

12437 US 153 (1978).
} 
decide whether a nearly-completed dam construction project breached the Endangered Species Act, in which case it would have to be abandoned, because it threatened the only habitat of the snail darter: '... a three-inch fish of no particular scientific, aesthetic, or economic interest .... ${ }^{13}$ The majority held that, when the text of a statute is clear, courts cannot refuse to apply the plain meaning of the text simply because this would produce an absurd result. Rather, they can refuse to apply the plain meaning of the text only if it is shown that the legislature intended a different result from that required by the plain meaning. In the present case, the wording of the Act was clear, the dam construction project was in breach of it, and it was not shown that the legislature intended a different result. Therefore, the majority held, the project must be halted. The minority disagreed, holding that the Act did not apply to projects that had already commenced before the Act was passed, since the alternative interpretation leads to an absurd result and the court should accept such an interpretation only if it is shown that that result was intended by the legislature. This, says Dworkin, appears to be a theoretical disagreement: the judges agreed about the relevant historical facts, but disagreed about what law was made by the Endangered Species Act. ${ }^{14}$

According to Dworkin, positivists have developed two ways of trying to explain away the appearance of theoretical disagreement in cases like Hill. ${ }^{15}$ The first involves arguing that the existing law did not provide answers to the questions in

\footnotetext{
13 Shapiro (n 1) 37-8.

${ }^{14}$ B Leiter, 'Explaining Theoretical Disagreement', 76 University of Chicago L Rev 1215-50, 1236-7 (2009) denies that Hill even appears to involve a theoretical (as opposed to empirical) disagreement. I think he is wrong about this (at the very least, the majority thought that its dispute with the minority was not simply about the empirical facts: Hill (n 12) 194). However, Leiter concedes that there are other cases that do appear to involve theoretical disagreement, and anyone who agrees with him could substitute one of those cases for Hill.

${ }^{15}$ Dworkin focuses on positivism because he regards it as the most influential of the theories that deny that theoretical disagreement exists (LE 33), and because it supports the plain fact view (LE 37).
} 
Dworkin's sample cases, and so the judges had to make new law to resolve those cases. They disagreed about what law they should make, but pretended to disagree about what the law already was in order to conceal their law-making role. The second involves arguing that the disagreements in the sample cases were 'borderline' disputes about the imprecise boundaries of the rule the judges all shared for determining the content of the law. On this view, legal officials share a rule setting out the grounds of law, and so - in the vast majority of cases - agree about how to determine the content of the law. However, the precise scope of that rule is occasionally unclear, causing legal officials to disagree.

Dworkin offers several objections to each of these arguments, but I shall sketch only one ground on which he rejects each. With regard to the first argument, he contends that there is no evidence that judges engage in such pretence. Indeed, the evidence suggests the opposite, since judges sometimes state (in cases where there appears to be theoretical disagreement) that what the law is conflicts with their views about what it should be. This appears inconsistent with the claim that judges pass off their views about what the law should be as views about what the law already is. With regard to the second argument, Dworkin contends that the disagreement in Hill was a 'pivotal' dispute about how to determine the content of the law on any occasion involving a statute. Rather than disagreeing about the precise scope of a rule they all shared, the judges in Hill offered fundamentally different tests for determining what law is made by a statute.

Dworkin concludes that we need a better account of disagreement about the law than we currently have. Most contemporary theories of law deny that theoretical 
disagreement exists. Yet the sample cases suggest that such disagreement is commonplace, and positivists' attempts to explain away the appearance of theoretical disagreement are unsuccessful. This need for a better account of disagreement about the law motivates Dworkin's treatment of law as an interpretive concept in Chapters 2 and 3 of Law's Empire. I will call his thesis that law is an interpretive concept 'interpretivism'; 16 one of its major strengths, according to Dworkin, is that it can account for theoretical disagreement.

\section{B. Types of Theoretical Disagreement}

Theoretical disagreement can take several different forms. To see this, let us begin by distinguishing two questions: 1) what sources of law are there in a particular jurisdiction; and 2) what effect does a given source of law have on the content of the law. In answering the first question, we are concerned with whether (say) legislation affects legal rights, responsibilities, etc qua legislation; in answering the second question, we are concerned with what effect it has (for example, is this determined by the plain meaning of the text, the legislators' intentions, moral considerations, or some combination of these?).

When Dworkin first introduces the notion of theoretical disagreement, his example concerns the first question. He asks us to imagine two lawyers who disagree about what the law is because they disagree about whether statutes and precedents exhaust the sources of law in their jurisdiction (LE 5). By contrast, cases like Hill

\footnotetext{
16 This term appears to have been coined by Nicos Stavropoulos: N Stavropoulos, 'Interpretivist Theories of Law' in EN Zalta (ed), The Stanford Encyclopedia of Philosophy <http://plato.stanford. edu/archives/entries/law-interpretivist/> (accessed 3 March 2010). (Note that Dworkin's claim that law is an interpretive concept should be distinguished from the particular interpretive theory he offers, which he labels 'law as integrity'.)
} 
concern the second question: the judges agreed that legislation is a source of law, but disagreed about what effect legislation has on the content of the law.

This reveals two forms theoretical disagreement can take. What the grounds of law are depends on how we answer both of the questions distinguished above, since which propositions of law are true depends not only on what sources of law there are, but also on what effect those sources have on the content of the law. Thus, disagreement about the answer to either question counts as theoretical disagreement.

There are further types of theoretical disagreement. ${ }^{17}$ If legislation is a source of law, presumably there is something that determines that it is. Whatever that something is, it helps determine which propositions of law are true, and so counts among the grounds of law. If legal officials disagree about what that something is, this is a type of theoretical disagreement. Similarly, there could be disagreement not only about what effect a given source of law has on the content of the law, but also about what determines what effect that source has. For example, there could be disagreement not only about what the correct theory of statutory interpretation is, but also about what determines which theory is correct. This, too, would be a theoretical disagreement.

Thus, theoretical disagreement encompasses not only disputes about what sources of law there are, and about what effect a given source has on the content of the law, but also disputes about what determines what sources of law there are and what determines what effect a given source has. (These four types of theoretical

\footnotetext{
${ }^{17}$ I am grateful to the anonymous referee for very helpful comments on this issue.
} 
disagreement reflect four types of grounds of law; I shall call the first two the 'shallower' grounds of law, and the second two the 'deeper' grounds of law.) Orthodox positivists would point to agreement among legal officials as constituting the deeper grounds of law. They claim that whether legislation is a source of law, or whether a particular theory of statutory interpretation is correct, depends on whether legal officials generally agree that it is. ${ }^{18}$ However, certain general truths about the nature of law also count among the deeper grounds of law. For example, if exclusive legal positivists are right, morality is not a source of law in the United States (or anywhere else), and the considerations that show they are right count among the grounds of law (since those considerations help determine what the sources of law are in the United States). Hence, a dispute between exclusive legal positivists and their opponents counts as a theoretical disagreement. ${ }^{19}$

To avoid misunderstanding, I should add that my concern in this Section has been simply to elucidate the different types of theoretical disagreement, not to argue that each of these types of disagreement poses a problem for positivists. That theoretical disagreement can take these different forms will prove important, especially when we consider in Part 5 how positivists might respond to the ATD.

\section{Why Interpret the ATD in This Way?}

\footnotetext{
${ }^{18}$ A (partial) exception is Joseph Raz, who claims that general truths about the nature of law have implications for which theory of statutory interpretation is correct: J Raz, 'Intention in Interpretation' in RP George (ed), The Autonomy of Law (OUP, Oxford 1996). If Raz is right, this simply provides a further illustration of the next point made in the text.

${ }^{19}$ Note that there is a clear connection between this understanding of the grounds of law and Dworkin's denial that there is a bright-line distinction between jurisprudence and any aspect of legal practice, and his contention that the soundness of any legal argument depends in part on the kind of abstract foundation that competing theories of law purport to offer: LE 90.
} 
So far, I have presented only part of my interpretation of Chapter 1. I have set out the ATD, but have not yet considered the SSA. Already, however, we can see that my interpretation differs dramatically from standard interpretations of Chapter 1. Rather than interpreting Dworkin as seeking to refute positivism or as defending 'normative jurisprudence', I regard his goal as being to refute any theory of law that denies that theoretical disagreement exists. Moreover, my interpretation allocates an important role to Dworkin's sample cases, since they provide evidence that theoretical disagreement does exist. Standard interpretations of Chapter 1, by contrast, regard Dworkin as attacking criterialism, and so either ignore his reference to the sample cases or else regard that reference as deeply confused (since those cases cannot be used to refute criterialism). ${ }^{20}$ Since Dworkin spends a third of Chapter 1 setting out the sample cases, an interpretation that allocates an important role to those cases is (everything else being equal) preferable to one that does not. Similarly, an interpretation that does not regard his reference to those cases as deeply confused is preferable to one that does.

This leads into the main reason for preferring my interpretation to standard interpretations of Chapter 1. In Parts 4 and 5, I argue that my interpretation shows Dworkin's key argument to be much harder to refute than is generally realized. It will become apparent that the same cannot be said on standard interpretations of Chapter 1, and this provides a powerful reason to prefer my interpretation.

My interpretation of the ATD is, however, similar to Shapiro's. As already mentioned, Shapiro treats the ATD as an objection to positivism: positivists are

\footnotetext{
${ }^{20}$ I explain in Part 4 why Dworkin's critics believe that the sample cases cannot be used to refute criterialism.
} 
committed to there being agreement about the grounds of law, whereas the sample cases show that legal officials often disagree about those grounds. To some extent, this interpretation shares the advantages of my interpretation. They both allocate the same role to Dworkin's sample cases. And, for reasons similar to those canvassed in Parts 4 and 5, Dworkin's discussion is much stronger on Shapiro's interpretation than on standard interpretations. ${ }^{21}$

Nevertheless, there are two important differences between my interpretation of the ATD and Shapiro's. Firstly, Shapiro treats the ATD as an objection to positivism. One of his main concerns in his essay is to suggest that, while positivists have refuted Dworkin's earlier critique, ${ }^{22}$ they have largely overlooked the 'extremely powerful' critique of positivism that Dworkin offers in Chapter 1 (by which Shapiro means the ATD). ${ }^{23}$ By contrast, I interpret the ATD as an objection to any theory of law that denies that theoretical disagreement exists. Dworkin claims that positivists adopt theories of this sort, but they may not be the only legal philosophers who do so, and anyone who does so is vulnerable to the ATD. Thus, Dworkin's target is a certain picture of disagreement about law; he concentrates on positivists because they are the clearest and most influential adherents of this picture.

There are several reasons for treating the ATD as seeking to refute not only positivism, but any theory of law that denies that theoretical disagreement exists. As we have seen, Dworkin also discusses natural law theory and legal realism, on the basis that they too may deny that theoretical disagreement exists. It is difficult to

\footnotetext{
${ }^{21}$ Though it is not as strong as on my interpretation: see Section 5B.

${ }^{22}$ See Dworkin (n 9) ch 2.

${ }^{23}$ Shapiro (n 1) 35. Dworkin denies that the earlier critique differs in any important way from the later one, or that positivists have refuted the earlier critique: Ronald Dworkin, Justice in Robes (Belknap Press, Cambridge Mass. 2006) 233-4. I will not pursue this issue here.
} 
account for this if one treats the ATD as targeting only positivism. ${ }^{24}$ Moreover, Dworkin describes Law's Empire as a book '... about theoretical disagreement in law. It aims to understand what kind of disagreement this is and then to construct and defend a particular theory about the proper grounds of law.' (LE 11) It makes sense, then, to interpret the ATD as targeting any theory that denies that theoretical disagreement exists.

What about the second way in which my interpretation of the ATD differs from Shapiro's? Shapiro has too narrow an understanding of the grounds of law, and hence of theoretical disagreement. He proposes that we can translate between talk of criteria of legal validity and talk of the grounds of law by regarding a criterion of legal validity as testing whether certain grounds of law obtain in a particular case. ${ }^{25}$ However, as criteria of legal validity are normally understood by positivists, they specify what sources of law there are in the relevant jurisdiction and what effect those sources have on the content of the law. They do not set out general truths about the nature of law, even if these help determine what sources of law there are or what effect those sources have. ${ }^{26}$ By contrast, the grounds of law do include such general truths about the nature of law. Instead of Shapiro's proposed translation, we could say that - since the grounds of law are what determine the truth or falsity of propositions of law - they include not just the criteria of legal validity but also whatever determines that these are the criteria of legal validity. This will prove crucial when assessing Shapiro's response to the ATD in Section 5B.

\footnotetext{
${ }^{24}$ Note that the ATD's target is not limited to the plain fact view either, since this view is rejected by natural lawyers, all of whom - in one way or another - deny that the content of the law depends solely on plain facts.

${ }^{25}$ Shapiro (n 1) 40.

${ }^{26}$ Indeed, this provides the basis for an influential objection to the SSA, which I consider in Part 4.
} 


\section{The SSA}

\section{A. What is the SSA?}

I suggested earlier that the SSA is typically interpreted as critiquing criterialism, though there is disagreement about whether criterialism is Dworkin's ultimate target or whether he attacks criterialism in order to achieve some further goal (such as refuting positivism). By contrast, on the interpretation I defend in this Part, the SSA seeks to explain why most legal philosophers deny that theoretical disagreement exists when such disagreement appears to be commonplace. In doing so, the SSA shows that we can account for theoretical disagreement only if we reject (a variant of) criterialism. However, to treat the SSA simply as critiquing (a variant of) criterialism is to miss its connection to the ATD.

To see this, consider a puzzle raised by the ATD. The ATD contends that theoretical disagreement appears to be commonplace, and that positivists' attempts to explain away this appearance are unsuccessful. Why then, do most legal philosophers continue to defend theories that require them to deny that theoretical disagreement exists? If Dworkin is correct, such theories cannot account for a prominent feature of legal practice. How could most legal philosophers have failed to notice this?

The SSA seeks to answer these questions, and it begins by suggesting that some legal philosophers have a surprising reason for denying that theoretical disagreement exists: 
They say that theoretical disagreement about the grounds of law must be a pretense because the very meaning of the word 'law' makes law depend on certain specific criteria, and that any lawyer who rejected or challenged those criteria would be speaking self-contradictory nonsense. (LE 31)

On this view, when using the word 'law', we follow a shared rule setting out criteria that provide the word's meaning. We may not be aware of this rule - it may take a philosopher to identify it; indeed, philosophers may disagree about its content - but we all adhere to that rule (consciously or not) when using the word 'law' (LE 31-2).

This looks a lot like criterialism. However, there is an important difference between Dworkin's understanding of criterialism and the understanding of many of his critics. This difference concerns the criteria contained in the rule for using the word 'law'. Since the word 'law' can be applied to any legal system, many of Dworkin's critics have understandably assumed that these criteria must not be specific to any particular jurisdiction. ${ }^{27}$ However, this is not how Dworkin views them. He regards these criteria as setting out the grounds of law.. ${ }^{28}$ While I emphasized in Section 1B that the grounds of law include general truths about the nature of law, they also include many jurisdiction-specific factors. For example, international law may be a source of law in one domestic legal system but not another, and the correct approach to statutory interpretation can also vary between legal systems. ${ }^{29}$

\footnotetext{
${ }^{27}$ See Part 4 below. For an exception, see Shapiro (n 1) 54 n 57.

${ }^{28} \mathrm{See}$, eg, LE 32: 'We all use the same factual criteria in framing, accepting, and rejecting statements about what the law is ...'. See also LE 33 (referring to criteria for deciding '.. when propositions of law are true or false ...').

${ }^{29}$ It would seem to follow that, on Dworkin's understanding of criterialism, there is no rule governing how to use the word 'law' in general, but only rules governing how to use that word in particular jurisdictions, each rule setting out the grounds of law of a different jurisdiction. (Though, to the extent that the 'deeper' grounds of law include general truths about the nature of law, there will be some overlap between these different rules.) It would also seem to follow that the meaning of the word 'law' varies between jurisdictions.
} 
We will shortly consider why Dworkin treats the criteria contained in the rule for using the word 'law' as setting out the grounds of law. For now, the important point is that he has a different understanding of those criteria than many of his critics. I will mark this difference by treating these critics as being concerned with criterialism and Dworkin as being concerned with criterialism* ${ }^{*}$

Dworkin suggests that philosophers who accept criterialism* produce theories attempting to identify the criteria for using the word 'law'. He labels such theories 'semantic' theories of law (LE 32), and suggests that - while positivism is the most influential such theory - natural law theory and legal realism can also be seen as semantic theories. ${ }^{30}$

Someone who accepts a semantic theory of law cannot account for theoretical disagreement. Semantic theories accept criterialism*, and so claim that legal officials share a rule for using the word 'law' which contains criteria setting out the grounds of law. Thus, semantic theories are committed to there being agreement among legal officials about the grounds of law. ${ }^{31}$

The key point, though, is that it is their acceptance of criterialism ${ }^{*}$ that allegedly explains why most legal philosophers deny that theoretical disagreement

\footnotetext{
${ }^{30}$ Neither positivists nor natural lawyers can plausibly be seen as seeking to identify all the relevant criteria, since this would involve setting out the grounds of law of a particular legal system, whereas they are concerned with identifying general truths about the nature of law. However, perhaps they could be seen as seeking to identify the 'deeper' grounds of law, leaving the task of identifying the 'shallower' grounds of law to legal practitioners.

${ }^{31}$ Semantic theories should not be regarded as the sole target of the ATD. This would be to unduly limit the ATD, which targets any theory of law that denies that theoretical disagreement exists. In Part 5 , I argue that this includes orthodox positivism, even though orthodox positivism need not be a semantic theory of law.
} 
exists. Why do they accept criterialism*? Dworkin's answer is that they accept (perhaps subconsciously) the following argument:

If two lawyers are actually following different rules in using the word 'law,' using different factual criteria to decide when a proposition of law is true or false, then each must mean something different from the other when he says what the law is. Earl and Gray must mean different things when they claim or deny that the law permits murderers to inherit: Earl means that his grounds for law are or are not satisfied, and Gray has in mind his own grounds, not Earl's. ${ }^{32}$ So the two judges are not really disagreeing about anything when one denies and the other asserts this proposition. They are only talking past one another. (LE 43-4, emphasis in original, footnote added)

This argument, which Dworkin labels 'the semantic sting' (LE 45), concerns what is necessary for successful communication to occur. ${ }^{33}$ It contends that successful communication can occur only if both parties follow the same rules for using the words that they use. In discussing what the law is, for example, they can communicate successfully only if they share the same rule for using the word 'law'. Moreover, that rule must set out the grounds of law, since - if two people accepted different grounds of law - they would be talking at cross-purposes when discussing what the law is. They would each be concerned with whether different grounds of law are satisfied, as in the example of Earl and Gray.

\footnotetext{
${ }^{32}$ Earl and Gray were two of the judges in Riggs v Palmer 115 NY 506 (1889), which is another of Dworkin's sample cases. They disagreed about whether a beneficiary could inherit under an otherwise valid will, where he murdered the testator in order to inherit.

${ }^{33}$ Thus, we must distinguish the SSA (which is Dworkin's explanation of why most legal philosophers deny that theoretical disagreement exists) from the semantic sting (which is an argument about what is needed for successful communication to occur, and which Dworkin claims most legal philosophers accept).
} 
We can see now why Dworkin is concerned with criterialism ${ }^{*}$, not criterialism. He claims that most legal philosophers accept a certain picture of when successful communication is possible, a picture that suggests (via the example of Earl and Gray) that successful communication about law is possible only if the grounds of law are shared. Once one accepts this picture, one is very likely to endorse criterialism*. One is unlikely to claim that, when legal officials discuss what the law is, they fail to communicate successfully. However, according to the semantic sting, they can communicate successfully only if they share a rule for using the word 'law', a rule that sets out the grounds of law. This is precisely what criterialism ${ }^{*}$ asserts that we share when using the word 'law'.

In summary, the role of the SSA in Chapter 1 is to explain why most legal philosophers deny that theoretical disagreement exists, even though such disagreement appears to be commonplace. It does so by suggesting that they accept criterialism*, which commits them to denying that theoretical disagreement exists. And it claims that they accept criterialism ${ }^{*}$ because they are led astray by the semantic sting - that is, by a certain picture of what is necessary for successful communication to occur.

In the broader context of Law's Empire as a whole, the SSA plays a further role. The ATD has shown that we need a new jurisprudential theory that allows for theoretical disagreement. The SSA contends that most legal philosophers deny that such disagreement exists because they accept criterialism* and the semantic sting. This suggests that - to allow for theoretical disagreement - our new jurisprudential theory must reject criterialism* and replace the semantic sting with a better picture of 
what is necessary for successful communication to occur. Later in Law's Empire, Dworkin argues that interpretivism satisfies each of these desiderata.

\section{B. Why Interpret the SSA in This Way?}

My interpretation of the SSA is very different from standard interpretations. ${ }^{34}$ While I agree that the SSA is to be found in Chapter 1, it is not the key argument of that chapter. Nor is it intended as a refutation of positivism or a defence of "normative jurisprudence'. Rather, it seeks to explain why most legal philosophers deny that theoretical disagreement exists (a denial the ATD has already shown to be misguided). Moreover, whereas standard interpretations treat the SSA as concerned with criterialism, I regard it as concerned with a related but importantly different position - namely, criterialism* . Finally, while the SSA shows that we can account for theoretical disagreement only if we reject criterialism*, it does so in the course of explaining why most legal philosophers deny that theoretical disagreement exists.

Let me briefly mention two reasons for preferring my interpretation of the SSA. Firstly, it fits better with what Dworkin says in Chapter 1. He commences his discussion of the semantic sting by stating that positivists suffer from a 'block' (LE 43). He then seeks to diagnose what that block is. His diagnosis is that positivists are victims of the semantic sting: they believe that communication about law is possible only if legal officials agree about the grounds of law. This strongly suggests that -

\footnotetext{
${ }^{34}$ It is less clear whether my interpretation of the SSA differs from Shapiro's. Shapiro (n 1) 54 n 57 suggests that the SSA is used to explain why positivists hold that the grounds of law are fixed by consensus - namely, because they tacitly subscribe to criterialism ${ }^{*}$. This suggests that he might largely agree with my claim about the role of the SSA. However, later in the same footnote, he seems to treat the SSA as an objection to positivism - an objection which is independent of the ATD, and which can be disarmed by showing that positivism is not committed to criterialism*. Either way, he regards the SSA as clearly flawed: 54 n $57 \& 55$ n 58 .
} 
while the SSA is in some way concerned with positivism - it is not meant to refute positivism. Rather, it is meant to explain why positivists make the mistake of denying that theoretical disagreement exists. ${ }^{35}$

Secondly, standard interpretations of the SSA become less plausible once we distinguish the SSA from the ATD. Why would Dworkin follow up an objection to any theory that denies that theoretical disagreement exists with an objection to positivism or an attack on criterialism? On standard interpretations, either the SSA appears redundant (because it is unclear what it adds to the ATD) or Chapter 1 appears disjointed (because it is unclear how the SSA fits with the ATD). By contrast, my interpretation shows how the SSA fits with - but adds to - the ATD, by explaining why most legal philosophers make the mistake identified in the ATD.

\section{An Important Objection}

In this Part, I consider an important objection to my interpretation of Chapter 1. This objection arises out of the discussion of 'conventionalism' in Chapter 4 of Law'S Empire. Unlike semantic theories of law, conventionalism rejects criterialism ${ }^{*}$ and embraces interpretivism. It does not claim that legal officials share a rule for applying the word 'law'; rather, it presents itself as the best interpretation of legal practice. In other respects, however, conventionalism closely resembles 'semantic' versions of positivism. It claims that what sources of law there are in a particular legal system is determined by convention. For example, if legislation and precedents are sources of law, this is because there is a convention to that effect. The effect that a given source

\footnotetext{
${ }^{35}$ As we have seen, Dworkin focuses on positivism because it is the most influential of the theories that deny that theoretical disagreement exists, and because it supports the plain fact view.
} 
of law has on the content of the law is also determined by convention. For example, whatever canons of statutory interpretation exist in a particular legal system exist because they are conventionally accepted (LE 114-6).

It seems to follow that conventionalism has only a limited capacity to account for theoretical disagreement. It can account for disagreement about what I have called the 'deeper' grounds of law, since it does not claim that these are determined by convention. However, seemingly, it cannot account for disagreement about the 'shallower' grounds of law - about what sources of law there are, or what effect those sources have on the content of the law - since it claims that these grounds are determined by convention.

Yet Dworkin's sample cases involve disagreement about the 'shallower' grounds of law. Hill, for example, involves a dispute about what effect legislation has on the content of the law. This is precisely the sort of theoretical disagreement conventionalism seems unable to account for. Hence the problem for my interpretation of Chapter 1: as I have interpreted it, the discussion in that chapter appears sufficient to refute conventionalism, and yet in Chapter 4 Dworkin treats conventionalism as a potentially viable theory of law.

One might conclude that I am wrong to interpret Chapter 1 as an objection to any theory of law that denies that theoretical disagreement exists. Rather, one might argue, Chapter 1 is an objection to any theory of law that accepts criterialism*. This includes 'semantic' versions of positivism, which claim that positivism is true because it is entailed by the rule for using the word 'law' that we all share. However, it does 
not include conventionalism, which is an interpretive version of positivism (claiming that positivism is true because it shows legal practice in the best light). This explains why Dworkin discusses conventionalism in Chapter 4.

However, interpreting Chapter 1 as an objection to any theory of law that embraces criterialism* does not solve the puzzle presented above. On this alternative interpretation, what is meant to be the problem with embracing criterialism* ? The only plausible answer, given what is actually said in Chapter 1, is that embracing criterialism* leaves one unable to account for theoretical disagreement. This returns us to our original puzzle: if conventionalism, too, cannot account for the theoretical disagreements in Dworkin's sample cases, is it not also refuted by the discussion in Chapter 1? So why does Dworkin devote an entire chapter later in Law's Empire to considering the merits of conventionalism?

Thus, this puzzle does not provide a reason to reject my interpretation of Chapter 1 and embrace the alternative interpretation. Both face the challenge of explaining why Dworkin regards conventionalism as a potentially viable theory of law, given the discussion in Chapter $1 .{ }^{36}$ So let us address that challenge.

Dworkin acknowledges that its apparent inability to account for the theoretical disagreements in his sample cases poses a problem for conventionalism (LE 121-2). However, he argues, this problem is not fatal. Conventionalists could argue that the relevant conventions are very abstract (perhaps simply that legislation and precedents are sources of law). There is, they could argue, agreement on these very abstract

${ }^{36}$ Of these two interpretations, mine is the more charitable. I argue in Part 4 that Dworkin is wrong to suggest that most legal philosophers embrace criterialism*. On the alternative interpretation, this deprives Chapter 1 of most of its interest, but (I will argue) on my interpretation it does not. 
claims. While the sample cases show that there is disagreement about what these abstract conventions require in particular cases, this simply shows that the law sometimes runs out. This, the conventionalist claims, is because the law is limited to what everyone agrees follows from the abstract conventions.

Thus, conventionalism can account for the theoretical disagreements in Dworkin's sample cases. These are cases in which the law ran out, because legal officials disagreed about what result followed from the abstract conventions they all shared. Perhaps most cases that come before appellate courts are like this. But the vast majority of legal disputes never reach an appellate court, and this may be because everyone agrees about what result follows from the abstract conventions in those cases.

'Semantic' versions of positivism cannot make the same move. They deny that theoretical disagreement exists, and so are committed to claiming that - for any putative ground of law - legal officials agree about whether it is in fact a ground of law. However, the claim that the law is exhausted by convention (in the way just described) is controversial. It is disputed by most natural lawyers and by Dworkin. ${ }^{37}$ Moreover, it is a claim about the (deeper) grounds of law, since it purports to describe the role that convention plays in determining what sources of law there are and what effect those sources have on the content of the law. Therefore, it is not a claim that can be made by anyone who denies that theoretical disagreement exists. ${ }^{38}$

\footnotetext{
${ }^{37}$ It is also disputed by many inclusive legal positivists, who claim that the relevant conventions may include moral tests of legal validity and that legal officials could disagree about what those tests require without the law having run out.

${ }^{38}$ It might be responded that 'semantic' versions of positivism deny only that there can be theoretical disagreement among legal officials, whereas the dispute referred to in the text is between legal philosophers. I consider this sort of response in Section 5C.
} 
Conventionalism is better off in this respect. As an interpretive theory, it need not deny that theoretical disagreement exists. It does claim that the law is limited to what everyone agrees follows from certain abstract conventions. However, this does not mean that, for any putative ground of law, legal officials must agree about whether it is in fact a ground of law. For example, two judges - one of whom is an exclusive, and the other an inclusive, legal positivist - might disagree about the grounds of law in the United States, because they might disagree about whether morality is a source of law in the United States. However, they are likely to agree that legislation and precedents are sources of law, and in many cases they will also agree about what result follows from this. That is all the agreement the conventionalist requires; she does not also need agreement on whether morality is a source of law. Disagreement on this point simply shows that morality is not a source of law.

Thus, unlike 'semantic' versions of positivism, conventionalism is not vulnerable to the ATD, which explains why Dworkin offers a separate discussion of it in Chapter 4 of Law's Empire. Moreover, the reason why conventionalism is not vulnerable to the ATD is because it does not deny that theoretical disagreement exists. This suggests that I am right to regard the ATD as an objection to any theory of law that does deny the existence of theoretical disagreement. ${ }^{39}$

\section{Responding to the SSA}

\footnotetext{
39 Admittedly, this requires me to regard as misleading Dworkin's statement that the important difference between conventionalism and 'semantic' positivism is that the latter asserts that its claims are '... realized in and enforced by the very vocabulary of law ...' (LE 116). This assertion is important only in so far as it explains why 'semantic' positivism denies that theoretical disagreement exists.
} 
In the next two Parts, I consider how seriously we should take the ATD and the SSA when they are interpreted in the way I have suggested. Not only is this worth considering for its own sake, but it is also relevant when assessing my interpretation of Chapter 1. The stronger Dworkin's arguments are on my interpretation, the more reason there is to accept that interpretation.

Let us start with the SSA. Jules Coleman and Kenneth Himma both argue that Chapter 1 trades on confusion between criteria for applying the concept of law and criteria of legal validity. ${ }^{40}$ In presenting this objection, they focus on the following sentence in Chapter 1:41

\begin{abstract}
If two lawyers are actually following different rules in using the word 'law,' using different factual criteria to decide when a proposition of law is true or false, then each must mean something different from the other when he says what the law is. (LE 43, emphasis in original)
\end{abstract}

They suggest that, in this passage, Dworkin treats 'following different rules in using the word "law" as equivalent to "using different factual criteria to decide when a proposition of law is true or false'. At the very least, he implies that - according to the position he is considering - either of these entails that 'each [lawyer] must mean something different from the other when he says what the law is.' However, Coleman and Himma contend, while criterialism ${ }^{42}$ entails that two people who follow different rules for using the word 'law' must mean something different by that word, it does not

\footnotetext{
${ }^{40}$ Coleman (n 5) 180-2; Himma (n 3 ) 160-3.

${ }^{41}$ This is part of a longer passage quoted in Section 2A. In that passage, Dworkin presents the view of those philosophers who embrace the semantic sting.

42 As will become clear, Coleman and Himma interpret Dworkin as discussing criterialism, not criterialism*.
} 
entail that two people who use different criteria to decide whether a proposition of law is true must mean something different by the word 'law'. To think otherwise is to conflate two types of criteria: criteria for applying the concept of law (or the word 'law') and criteria of legal validity.

According to Coleman and Himma, we can see that these two types of criteria are distinct from the fact that criteria for determining whether a proposition of law is true are indexed to a particular legal system, whereas criteria for applying the concept of law are not. In other words, different legal systems have different criteria of legal validity, whereas the criteria for applying the concept of law must be applicable to all legal systems.

It follows, argue Coleman and Himma, that two people may share criteria for applying the concept of law and yet disagree about the criteria for determining whether a proposition of law is true, because they may belong to different legal systems with different criteria of legal validity.. ${ }^{43}$ Indeed, two people in the same jurisdiction can disagree about the criteria of legal validity without thereby disagreeing about the criteria for applying the concept of law. For example, they might agree that law is a contestable concept (i.e. that what the law is is always potentially disputable, and that these disputes must be settled by interpreting the law), and this might explain why they disagree about the criteria of legal validity.. ${ }^{44}$

\footnotetext{
${ }^{43}$ Though one might query whether this is a genuine disagreement, since each person is concerned with the criteria of legal validity of a different legal system.

${ }^{44}$ The example is Coleman's (Coleman (n 5) 182); Himma does not offer an example to illustrate this point. Moreover, Coleman's example is problematic: that two people agree that law is a contestable concept does not mean that they share criteria for applying that concept. To state that law is a contestable concept is not to provide criteria for determining when that concept applies; rather, it amounts to a concession that there are no shared criteria of this sort. However, it may be that Coleman's point is sound, even if his example is problematic.
} 
This is taken by Coleman and Himma to refute Dworkin's argument in Chapter 1. His sample cases may show that, in some jurisdictions, there is disagreement about the criteria of legal validity. However, this does not mean that there is disagreement about the criteria for applying the concept of law, and so does not undermine criterialism. Thus, even if positivism is committed to criterialism, Chapter 1 poses no threat to criterialism, and hence no threat to positivism. ${ }^{45}$

This objection has proven popular. ${ }^{46}$ However, if my interpretation of Chapter 1 is correct, the objection is fundamentally misguided. It poses no threat to the ATD, which is the key argument in Chapter 1 . The objection may show that criterialism can account for the theoretical disagreements in Dworkin's sample cases. Yet the ATD does not claim that criterialists cannot account for theoretical disagreement, but rather that most legal philosophers cannot. Indeed, criterialism does not feature in the ATD at all.

The objection may seem more promising if we regard it as targeting the SSA. Dworkin cannot plausibly contend that the reason why most legal philosophers deny that theoretical disagreement exists is because they accept criterialism, if criterialism can in fact account for theoretical disagreement. However, we have seen that Dworkin does not claim that most legal philosophers accept criterialism. Rather, he claims that they accept criterialism ${ }^{*}$. Even if criterialism can account for theoretical disagreement,

\footnotetext{
${ }^{45}$ Himma (n 3) 164-5 and Coleman (n 5) 155-6 both regard Chapter 1 as criticising positivists for accepting criterialism (though Coleman (n 5) 179-83 also regards it as a defence of 'normative juriprudence').

${ }^{46}$ For example, Hart and Kramer both offer variants of this objection: HLA Hart, The Concept of Law ( $2^{\text {nd }}$ edn Clarendon Press, Oxford 1994) 247; Matthew H Kramer, In Defense of Legal Positivism: Law without Trimmings (OUP, Oxford 1999) ch 6.
} 
criterialism $^{*}$ cannot, because it claims that there is agreement on the criteria setting out the grounds of law.

Coleman and Himma are also wrong to accuse Dworkin of confusing criteria for applying the concept of law with criteria of legal validity (or of implausibly ascribing such confusion to positivists). Rather, he is concerned with the criteria that set out the grounds of law. We have seen that the grounds of law include the criteria of legal validity, but also include general truths about the nature of law (which most positivists would regard as conceptual truths). Thus, Dworkin does not confuse criteria of legal validity with criteria for applying the concept of law (or claim implausibly that positivists do so). It is just that the distinction between these two types of criteria is not important for his purposes.

Coleman's and Himma's objection therefore fails. However, it suggests an alternative objection to the SSA which is successful. We have seen that Dworkin regards as unimportant the distinction between criteria of legal validity and criteria for applying the concept of law. However, in claiming that positivists accept criterialism*, Dworkin overlooks the fact that they do attach importance to this distinction. ${ }^{47}$ It is, therefore, implausible to claim that positivists adopt a position that, by focusing on the grounds of law, requires them to downplay the significance of this distinction.

That the SSA is an implausible explanation of why positivists deny that theoretical disagreement exists should not come as a surprise. The SSA claims that positivists - and perhaps other legal philosophers - accept criterialism*, and that they

\footnotetext{
${ }^{47}$ This is true not only of Coleman and Himma: see, eg, Raz (n 4) 27.
} 
do so because they share a certain view about when successful communication is possible. However, it seems improbable that most legal philosophers tacitly accept the same view about when successful communication is possible. Even if they did, it would not be the view Dworkin ascribes to them, which focuses on the grounds of law and so regards as unimportant the distinction between criteria for applying the concept of law and criteria of legal validity. ${ }^{48}$

The suggestion that positivists do not accept the criterialist view Dworkin ascribes to them in Chapter 1 is hardly novel. ${ }^{49}$ However, while this means that we must reject the SSA, doing so deprives Dworkin only of his explanation of why legal philosophers make the mistake identified in the ATD. It does not undermine the ATD. Dworkin may be right in claiming that most legal philosophers mistakenly deny that theoretical disagreement exists, even if he is wrong in suggesting that they do so because they embrace criterialism*.

Nor does the failure of the SSA undermine the larger project of Law's Empire. It is the ATD that demonstrates the need for an alternative jurisprudential theory that can account for theoretical disagreement. The failure of the SSA does not even undermine Dworkin's reason for concluding that this alternative theory must reject criterialism ${ }^{*} .50$ The problem with the SSA is not that criterialism ${ }^{*}$ can account for

\footnotetext{
${ }^{48}$ If criterialism* has the implications canvassed in $\mathrm{n} 29$ above, this would suggest a further reason for thinking that few legal philosophers accept criterialism*.

${ }^{49}$ See, eg, Shapiro (n 1) 54-5 n 58; Hart (n 46) 246-7. Note that, subsequent to Law's Empire, Dworkin offered an additional explanation of why many legal philosophers continue to embrace positivism namely, '... because it allows them to treat legal philosophy as an autonomous, analytic, and selfcontained discipline.' (Dworkin (n 23) 188)

${ }^{50}$ Since criterialism* is a rival to interpretivism, this conclusion is significant even if few legal philosophers accept criterialism*. (It might be thought that we should instead focus on those rivals to interpretivism that legal philosophers do endorse. However, it is not clear that legal philosophers have endorsed any genuine alternatives to interpretivism. Legal philosophers do provide accounts of the concept of law, but the ATD suggests that what we need is an account of the grounds of law.)
} 
theoretical disagreement; it cannot. Rather, the problem with the SSA is that there is good reason to think that most legal philosophers reject criterialism*, and so their denial that theoretical disagreement exists cannot be motivated by an acceptance of criterialism*. Thus, while my interpretation of Chapter 1 reveals the SSA to be mistaken, this undermines neither the key argument of that chapter (the ATD) nor the larger project of Law's Empire.

\section{Responding to the ATD}

\section{A. Orthodox Positivism}

We have seen that it is the ATD, not the SSA, which constitutes Dworkin's objection to most contemporary theories of law. Moreover, we have seen that Shapiro regards the ATD as posing a serious challenge to positivism. In this Part, I argue that Shapiro is right; indeed, the challenge is even more serious than he realizes.. ${ }^{51}$

If theoretical disagreement of the sort that appears to exist in Dworkin's sample cases is widespread, then orthodox positivism must be rejected. Recall that orthodox positivism asserts that, in any legal system, there is general agreement among the officials of that system about what the criteria of legal validity are. Orthodox positivism need not require unanimity among legal officials, but it does require sufficient agreement that we can say that this is the way in which they generally determine the content of the law. This agreement need not be express; it may be implicit in the way in which officials determine whether a norm is legally

\footnotetext{
${ }^{51}$ As we have seen, the ATD may target non-positivist theories as well. In this Part, however, I focus on positivism, since it is Dworkin's primary target.
} 
valid. However, for a legal system to exist, legal officials must generally agree (expressly or implicitly) about what the criteria of legal validity are. ${ }^{52}$

Orthodox positivism can plausibly be ascribed to Hart. He stresses that, for a legal system to exist, it is crucial '... that there should be a unified or shared official acceptance of the rule of recognition containing the system's criteria of validity. ${ }^{, 53}$ While a court may occasionally deviate from the rule of recognition, legal officials as a whole must generally regard such deviations '... as lapses from standards, which are essentially common or public.' ${ }^{54}$ The most natural way of reading these claims is as asserting that officials must generally agree about what the criteria of legal validity are. Hart does allow that there could be widespread disagreement among officials about a limited number of these criteria without the legal system ceasing to exist, but he regards such a legal system - in which the 'unity among officials' partly breaks down - as 'pathological'..55

More generally, orthodox positivism appears to be entailed by the claim, accepted by many positivists, that law is a conventional practice. For law to be a conventional practice, must it not be the case that it exists by virtue of a convergence of behaviour and attitudes among legal officials? And does this not require that legal officials agree (expressly or implicitly) about what the criteria of legal validity are?

\footnotetext{
${ }^{52}$ Both exclusive and inclusive legal positivists could accept orthodox positivism. Orthodox positivism need not accept the plain fact view; nor need it accept criterialism*.

${ }^{53}$ Hart (n 46) 115. See also 116 (the existence of a legal system depends on the acceptance, among legal officials, '.. of common standards of legal validity.').

${ }^{54}$ Ibid 116.

${ }^{55}$ Ibid 122-3. This claim should be distinguished from Hart's further claim that the criteria that officials generally share are 'open textured'. According to Dworkin, the latter claim represents the second way in which positivists seek to explain away the appearance of theoretical disagreement (see Section 1A).
} 
However, while orthodox positivism can account for some theoretical disagreements, it cannot account for the disputes in Dworkin's sample cases, at least not if these are indicative of widespread theoretical disagreement. ${ }^{56}$ Perhaps orthodox positivism can allow for disagreement about what I have called the 'deeper' grounds of law, since it claims only that there must be agreement on the criteria of legal validity. ${ }^{57}$ However, it can allow for only limited disagreement about the 'shallower' grounds of law - about what sources of law there are in a particular jurisdiction, or what effect a given source has on the content of the law. It cannot allow for widespread disagreement about the 'shallower' grounds of law, because they constitute the criteria of legal validity on which orthodox positivists claim that legal officials generally agree. Yet we have seen that Dworkin's sample cases involve this type of disagreement. If this type of disagreement is widespread, we must abandon orthodox positivism, a position that Hart arguably held and that many other positivists may well accept. This, one might say, is the real 'sting' in Chapter 1.

\section{B. Shapiro's Response to the ATD}

One obvious way in which positivists could respond is by denying that there is widespread theoretical disagreement of the sort that poses a problem for orthodox positivism. I consider this response in the next Section. In the present Section, I discuss another way in which positivists could respond to the ATD - namely, by abandoning orthodox positivism in favour of a different type of positivist theory. This

\footnotetext{
${ }^{56}$ Widespread disagreement exists where large numbers of legal officials take different sides on an issue. A 50-50 split is not required: if 55\% of legal officials treated morality as a source of law and $45 \%$ did not, this would preclude the general agreement required by orthodox positivism. (When the US Supreme Court splits 5-4, we do not say that there is general agreement among the judges.) Nor is it necessary that the disagreement be express, as opposed to being implicit in officials' practices.

${ }^{57}$ Though see Section 5C.
} 
is the move Shapiro makes: he defends a form of positivism that does not regard legal practice as conventional and so (he claims) can account for theoretical disagreement. $^{58}$

Shapiro is concerned with 'ascertaining proper interpretive methodology, 59 which I take to mean the correct way of identifying the law's content. He advocates a version of positivism according to which the proper interpretive methodology is the one that best fits with the purposes that the designers of the legal system ('the lawdesigners') had in designing that system. ${ }^{60}$ Thus, the relevant purposes are not those underlying individual laws, but rather the broader political objectives that the lawdesigners sought to achieve through the legal system as a whole. The correct interpretive methodology is the one that best fits with these broader objectives. ${ }^{61}$

Shapiro contends that this is a version of positivism, since the questions 'what purposes did the law-designers have?' and 'which interpretive methodology best fits with those purposes?' are non-moral questions. (For one thing, the law-designers may have had morally undesirable aims.) Yet he also contends that it allows for theoretical disagreement, because people may disagree about what purposes the law-designers had or which methodology best fits with those purposes, leading them to disagree

\footnotetext{
${ }^{58}$ Coleman (n 5) 96-100 argued that the existence of certain conventional practices (such as legal officials' practice of evaluating conduct in light of criteria of legal validity) does not require that there be agreement about the content of the practice, because conventional practices of this sort are 'shared cooperative activities'. In this way, he claimed, positivists can allow for theoretical disagreement while maintaining that legal practice is conventional. Despite the obvious differences from Shapiro's view, Coleman's position also involved rejecting orthodox positivism in an attempt to account for theoretical disagreement. However, it appears that Coleman has since abandoned this position: see Matthew Noah Smith, 'The Law as a Social Practice: Are Shared Activities at the Foundations of Law?' (2006) 12 Legal Theory 265-92, $276 \mathrm{n} 36$.

${ }^{59}$ Shapiro (n 1) 43.

${ }^{60}$ Shapiro takes a broad view of who counts as a law-designer. In the US, this includes ' ... not only the framers and the ratifiers of the Constitution of 1787, but the numerous agents over the past two hundred years who have changed the complexion of the system.' (ibid $55 \mathrm{n} 61$ )

${ }^{61}$ Ibid 45-7.
} 
about the correct way to identify the law's content. ${ }^{62}$ If so, it is a version of positivism that is not vulnerable to the ATD.

Shapiro acknowledges the similarities between his version of positivism and Dworkin's interpretivism. ${ }^{63} \mathrm{He}$ agrees with Dworkin that legal practice is not necessarily conventional (since there can be widespread disagreement about the correct way to identify the law's content). He also accepts that, in jurisdictions where theoretical disagreement is common, ascertaining the proper interpretive methodology requires us to identify the purposes of the legal system. Finally, he agrees with Dworkin that, in such cases, the proper interpretive methodology is the one that best fits with those purposes. These points of agreement provide Shapiro with his response to the ATD: it is his concern with the law-designers' purposes, and with identifying which interpretive methodology best fits with those purposes, which (allegedly) enables him to explain how legal officials can disagree about the grounds of law.

Nevertheless, Shapiro's position is importantly different from Dworkin's. For Shapiro, unlike Dworkin, what the purposes of a legal system are is a question of social fact, since it depends on what objectives the law-designers in fact had. Which interpretive methodology best fits with those purposes is also a non-moral question: unlike Dworkin's, Shapiro's account of fit has no moral content. Nor does Shapiro's

\footnotetext{
${ }^{62}$ Disputes about which interpretive methodology best fits with the law-designers' purposes clearly count as theoretical disagreements. It is less clear whether disputes about what purposes the lawdesigners had also count. When arguing that the dispute in Hill is a theoretical disagreement, Dworkin emphasizes that it is not about what purposes Congress had. This suggests that he might not treat a dispute about what purposes the law-designers had as a theoretical disagreement. However, on Shapiro's version of positivism, the law-designers' purposes count among the 'deeper' grounds of law, since they help determine which interpretive methodology is correct. Thus, to account for disagreement about those purposes is, arguably, to account for some of the phenomena that Dworkin challenges positivists to explain.

${ }^{63}$ Shapiro (n 1) 43-4.
} 
This article was first published in the

(2010) 30(4) Oxford Journal of Legal Studies 635-661

account of interpretation have a second 'dimension', of justification or moral soundness.

The key question for our purposes, however, is whether Shapiro succeeds in disarming the ATD. His version of positivism allows for disagreement regarding some of the grounds of law. It allows for disagreement about what the law-designers' purposes are, and about which interpretive methodology best fits with those purposes. However, legal officials disagree not only about these matters, but also about whether the law-designers' purposes are relevant to determining the content of the law (and, if so, in what way they are relevant). For example, some judges deny that constitutional interpretation is concerned with implementing (via either a textualist or intentionalist analysis) the broad political objectives of the law-designers; they rail against '... freezing [constitutional] provisions within the restricted horizons of a bygone era. ${ }^{64}$

It might be thought to be a trivial task for Shapiro to account for these types of theoretical disagreement. He denies that legal practice must be conventional, and so need not claim that there is agreement about the grounds of law. So why should he be perturbed by the fact that legal officials disagree about whether the law-designers' purposes are relevant to determining the content of the law?

However, while Shapiro denies that legal practice must be conventional, he does claim that what makes his theory a positivist theory is that '... it roots interpretive

\footnotetext{
${ }^{64}$ Sir Anthony Mason, 'The Role of a Constitutional Court in a Federation: A Comparison of the Australian and the United States Experience' in The Mason Papers (ed by G Lindell) (Federation Press, Annandale 2007) 135. Even if one is not persuaded by this example, it is clearly not the case that Shapiro's account of how to determine the content of the law is universally accepted by legal officials. Disagreement about whether that account is correct is itself a form of theoretical disagreement that needs to be explained.
} 
methodology in social facts. ${ }^{65}$ This suggests that it may not be a trivial task for Shapiro to account for disagreement about the relevance of the law-designers' purposes, since he must do so in a way that is consistent with his claim that interpretive methodology is rooted in social facts. If the social facts that determine the relevance of the law-designers' purposes are anything like the 'plain facts' Dworkin has in mind, they should be readily accessible to legal officials. How, then, could there be disagreement among officials about the relevance of the law-designers' purposes? Alternatively, the social facts in question might be complex sociological facts. Such facts might be less accessible to legal officials, which would explain how they can disagree about the relevance of the law-designers' purposes. However, Shapiro would need to show that these complex sociological facts are not normative (at least, not in a way that is problematic for legal positivists). In doing so, he would need to confront the view, held by many sociologists, that such facts are normative. ${ }^{66}$

Clearly, this is insufficient to refute Shapiro's version of positivism. It does, however, show that his response to the ATD is incomplete. He shows that his version of positivism can account for some theoretical disagreements, such as disputes about which interpretive methodology best fits with the law-designers' purposes. However, he does not show that it can account for more fundamental theoretical disagreements, such as disputes about whether the law-designers' purposes are relevant to determining the content of the law and (if so) in what way.

Moreover, I want to suggest that the reason why Shapiro's response is incomplete is because he under-estimates the scope of the ATD. He recognizes that

\footnotetext{
${ }^{65}$ Shapiro (n 1) 48 (emphasis in original).

${ }^{66}$ See, eg, RM Unger, Law in Modern Society: Toward a Criticism of Social Theory (Free Press, New York 1976) ch 1. I am grateful to Patrick Emerton for helpful discussions of this issue.
} 
Dworkin challenges positivists to account for disagreement about the criteria of legal validity. However, he does not seem to realize that Dworkin's challenge goes further. We have seen that the grounds of law are not limited to the criteria of legal validity; they also extend to whatever determines that these are the criteria of legal validity. On Shapiro's version of positivism, this includes not only the law-designers' purposes, but also the considerations that determine that these purposes are relevant and how they are relevant. The ATD challenges positivists to account for disagreement about these matters as well, and Shapiro has not yet met that challenge.

\section{Defending Orthodox Positivism}

As mentioned earlier, there is another way in which positivists could respond to the ATD - namely, by denying that there is widespread theoretical disagreement of the sort that poses a problem for orthodox positivism. This typically involves contending that what appears to be theoretical disagreement is in fact something else. For example, Hart suggests in the Postscript to The Concept of Law that what appears to be theoretical disagreement is really disagreement about the application (not the content) of the criteria of legal validity. ${ }^{67}$ And Brian Leiter contends that legal officials are either disingenuous or simply wrong when (in cases of apparent theoretical disagreement) they present their views in ways that make it seem that they are disagreeing about what the criteria of legal validity are. Pointing to the fact that relatively few legal disputes ever come before a court, Leiter argues that even apparent theoretical disagreements are sufficiently uncommon that this explanation of them is unproblematic. Indeed, it is preferable to Dworkin's explanation because it is

\footnotetext{
${ }^{67}$ Hart (n 46) 258-9.
} 
part of a positivist theory that has significant explanatory advantages over Dworkin's theory (such as its ability to account for widespread agreement about the law).. ${ }^{68}$

I cannot determine here whether either of these attempts to account for theoretical disagreement is ultimately successful. However, I will seek to show that there is at least one way in which the challenge facing Hart and Leiter is greater than they realize. When Hart and Leiter deny that theoretical disagreement exists, what they are concerned to deny is the existence of disagreement about the criteria of legal validity. These criteria, they claim, are settled by agreement among legal officials, and so cannot be the subject of (widespread) disagreement among those officials. However, we have seen that debates about the 'deeper' grounds of law may have implications for the criteria of legal validity. For example, if morality is necessarily a source of law, or necessarily not a source of law, this has obvious implications for what the criteria of legal validity are in any legal system. Hart and Leiter presumably do not want to deny the existence of debates about these matters, but nor can they easily reconcile the existence of those debates with their claim that there must be general agreement about the criteria of legal validity.

Let us consider the two horns of this dilemma more carefully. Firstly, orthodox positivists could deny that there can be widespread disagreement among legal officials about general truths about law (such as whether morality is necessarily a source of law). It is true that these sorts of debates usually occur among legal philosophers, not legal officials. However, there seems to be no reason why there

\footnotetext{
${ }^{68}$ Leiter (n 14). Note, however, that it is not clear that orthodox positivists can take comfort in the fact that legal officials agree on the answer to most legal questions, since they need to show that officials generally use the same criteria of legal validity when arriving at those answers. (For Leiter's response, see 1229-32.)
} 
could not be a legal system in which officials commonly participate in the same debates about the nature of law that legal philosophers engage in. (Orthodox positivism is meant to capture a necessary truth about all possible legal systems; it cannot be defended by pointing out that there are some, or even many, legal systems in which officials do not typically engage in such debates.)

This leaves the second horn of the dilemma. Orthodox positivists could argue that widespread disagreement among legal officials about general truths about law does not prevent them from generally agreeing about what the criteria of legal validity are. However, it seems that participating in the debate between exclusive legal positivism and (some forms of) natural law theory commits legal officials to disagreeing about the criteria of legal validity in their jurisdiction, since some will be committed to claiming that morality is not a source of law while others will be committed to claiming that it is. Admittedly, legal officials might not always recognize these commitments, or might participate in these debates in a cynical attempt to buttress a particular conclusion in a particular case. However, it does not seem that this must necessarily be the case. Nor can these disputes easily be passed off as being about what the criteria of legal validity should be, or about the application - as opposed to the content - of the criteria of legal validity (in the way that Leiter and Hart seek to explain many apparent theoretical disagreements). 
This does not show that orthodox positivism is untenable. ${ }^{69}$ However, it does suggest that the ATD poses a serious challenge to orthodox positivism, and that meeting this challenge will prove more difficult than most of Dworkin's critics realize.

\section{Conclusion}

Shapiro is right to claim that there are two arguments - the ATD and the SSA - in Chapter 1 of Law's Empire. However, I have contested his understanding of those arguments. The ATD is an objection to any theory of law that denies that theoretical disagreement exists; the SSA, by contrast, is an explanation of why most legal philosophers adopt such theories. While the SSA is an implausible explanation of why most legal philosophers deny that theoretical disagreement exists, this does not undermine the ATD's contention that they are wrong to do so. Indeed, the ATD represents a serious challenge to most contemporary theories of law, and particularly to positivism. Whether positivists respond by attempting to explain away the appearance of theoretical disagreement, or by adopting a version of positivism that

\footnotetext{
${ }^{69}$ For example, Hart might argue that - if these disputes are widespread among legal officials - this simply shows that the legal system in question is 'pathological': see text for $\mathrm{n} 55$ above. I should briefly mention two other ways in which orthodox positivists could seek to account for theoretical disagreement. Firstly, they might argue that disputes among legal officials about the criteria of legal validity are consistent with the hypothesis that officials share such criteria, since officials might have only a limited ability to identify the criteria they all use in practice. (For an analogous argument, concerning the criteria for applying the concept of law, see Raz (n 4).) This response to the ATD is not without its own difficulties, however. In cases like Hill, not only do the different judges say incompatible things, but they advocate incompatible results. In virtue of what, then, do they share criteria of legal validity?

Secondly, orthodox positivists might argue that there is nothing to prevent them from accounting for theoretical disagreement in the same way conventionalism does. On this view, orthodox positivism does not claim that, for any putative criterion of legal validity, officials must generally agree about whether it is a criterion of legal validity. Instead, it claims only that the criteria of legal validity are limited to whatever legal officials agree are criteria of legal validity. On this view, disagreement about whether morality is a source of law simply shows that it is not. (I do not think that this is the view held by most contemporary positivists. It also has its own difficulties. For example, if Dworkin is right about how prevalent theoretical disagreement is in Anglo-American legal systems, this view results in those jurisdictions having very thin criteria of legal validity: see Dworkin (n 23) 194.)
} 
This article was first published in the

(2010) 30(4) Oxford Journal of Legal Studies 635-661

seeks to allow for theoretical disagreement, they have much work to do to show that they are not vulnerable to the ATD. 


\section{University Library}

\section{- M M I N E R VA A gateway to Melbourne's research publications}

Minerva Access is the Institutional Repository of The University of Melbourne

Author/s:

Smith, D

Title:

Theoretical Disagreement and the Semantic Sting

Date:

2010

Citation:

Smith, D. (2010). Theoretical Disagreement and the Semantic Sting. Oxford Journal of Legal Studies, 30 (4), pp.635-661. https://doi.org/10.1093/ojls/gqq019.

Persistent Link:

http://hdl.handle.net/11343/241640 